bacterium's genome into random fragments, and then uses the polymerase chain reaction (PCR) to amplify some of the fragments. Sequence variation between strains, and variation in the length of regions in which small stretches of sequence are repeated, results in a different pattern of amplified fragments for each strain. Data derived from the AFLP

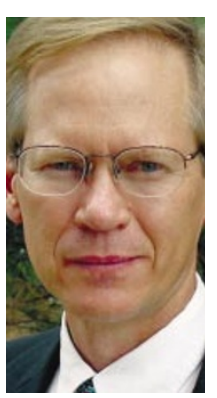
technique are held on databases at the NAU and at the Los Alamos National Laboratory in New Mexico.

But Keim's lab has also adapted a more precise test called multilocus VNTR (variablenumber tandem repeat) analysis, or MLVA, for Taking the strain: use with microorganPaul Keim. isms. With MLVA, researchers use PCR to amplify regions of the genome containing repeated sequences and so develop a genetic fingerprint for a strain or species. MLVA has so far been performed on about 400 of the 1,200 known strains of B. anthracis.

The genome of $B$. anthracis contains short sequences of DNA that, depending on the strain, are repeated a different number of times at certain loci. Keim's group has published findings on eight such markers used to probe these loci, using a technique that is similar to that used in genetic fingerprinting for paternity suits or criminal investigations. Keim's team has a total of about $50 \mathrm{~B}$. anthracis markers at its disposal, and is working on more markers for the roughly 1,000 VNTR loci in the bacterium's genome. "This is a highly precise method that also can be used for tuberculosis, Escherichia coli and other pathogens," says Keim.

It takes about 12 hours for Keim's lab to analyse an anthrax sample. Once a strain is identified, investigators can try to match it to its original source - but this is not always easy. The Ames strain, for example, has been passed around the world by researchers - the sample held by the NAU came from Britain's chemical and biological defence facility at Porton Down, which received it from the US Army Medical Research Institute of Infectious Diseases at Fort Detrick in Maryland.

In the future, analysis of anthrax will get a boost from the sequencing of a derivative of the Ames strain by The Institute for Genomic Research (TIGR) in Maryland. Timothy Read, a bacterial genomicist at TIGR, says he expects to close the final gaps in the strain's sequence in the next few months. Other strains will also be sequenced in the near future.

http://herb.bio.nau.edu/ genetics/project3.htm

\title{
Scientific leaders respond to US government's call to arms
}

\section{Jonathan Knight, San Francisco}

Leaders of the US scientific community are developing plans to work closely with government agencies and the military in the fight against terrorism.

On 26 September, for example, Bruce Alberts, president of the National Academy of Sciences, convened a meeting of 30 prominent scientists and security experts to discuss the role of science in the aftermath of the 11 September attacks on New York and Washington.

Those attending included Norman Augustine, chairman of aeronautics company Lockheed Martin; John Marburger, director of the Department of Energy's Brookhaven National Laboratory and President George W. Bush's nominated science adviser; Wolfgang Panofsky, a director of the Stanford Linear Accelerator Center; former senator Sam Nunn; and James Woolsey, former head of the Central Intelligence Agency.

"All were clearly concerned that the scientific and technical community hasn't played an important role in the issue of dealing with organized terrorism," says Kumar Patel, a former president of the American Physical Society, who also attended the meeting.
Several federal agencies, including the National Science Foundation and the Defense Advanced Research Projects Agency, currently fund counter-terrorism research. But according Maxine Singer, president of the Carnegie Institution, who was present at the meeting, they sometimes fail to draw on the full creative potential of the academic community. "Things have become institutionalized," she says.

Both the White House Office of Science and Technology Policy and the Pentagon's Technical Support Working Group have approached the academy complex to ask for input, says Bill Colglazier, executive director of the National Research Council. "They want cutting-edge people to help with brainstorming and advising," he says.

To coordinate this input, the academies are planning to spend $\$ 500,000$ of their own money to help create a task force with an anti-terrorist research agenda, called the Multi-Agency Program Plan for Science and Technology. Lewis Branscomb, a technology-policy specialist at Harvard University, and Richard Klausner, a former director of the National Cancer Institute, are leading the project.

\section{Gaps remain in Japan's biodefences}

\section{David Cyranoski, Tokyo}

Japan remains vulnerable to bioterrorist and chemical attacks, citizen groups and biomedical researchers are warning. Despite

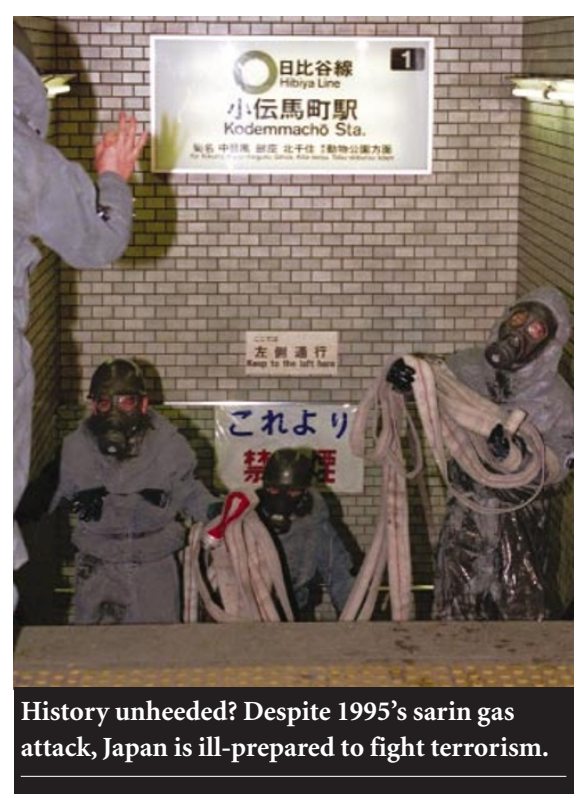

suffering the 1995 sarin nerve-gas attack on the Tokyo subway, the government has not taken sufficient action, the groups say.

"Now many hospitals and clinics are aware of emergency measures for sarin treatment," says Masanori Fukushima, an epidemiologist at Kyoto University, "but there is no preparation for recognizing victims of bioterrorism."

Yukitatsu Kawamoto, of the Citizen's Centre for the Prevention of Biohazards in Chiba, notes that in 1993 Aum Shinrikyo, the cult behind the sarin attack, sprayed a non-virulent strain of anthrax from the roof of its Tokyo headquarters. "The authorities never tracked down where Aum got it, and they haven't taken measures to account for such materials since then," he says.

And last week Yasuo Fukuda, the government's chief cabinet secretary, admitted that Japan's anti-terrorism preparations are inadequate.

But Toshinobu Sato, director of the Office of Health Crisis Management, claims that security at health-ministry institutes is sufficient to prevent anyone from removing potential biological weapons. 